\title{
Use of activated charcoal in the radioimmunoassay of human growth hormone in plasma
}

\author{
H. S. JACOBS \\ From the Institute of Clinical Research, the Middlesex Hospital Medical School, London
}

SYNOPSIS The use of activated charcoal in the radioimmunoassay of human growth hormone is described. The method permits the rapid separation of bound from free labelled human growth hormone in large batches and affords a quick method for screening iodination eluates. The necessity for an equality of protein concentration for the incubation and the separation procedure is emphasized. The method is simple, reliable and rapid, and the sensitivity obtained compares favourably with that of other methods of separation.

Modern endocrine investigation and research relies increasingly upon radioimmunoassays to provide answers to clinical problems, and assays which only a few years ago were considered research procedures are now becoming routine in many departments. The increasing demand for these procedures has prompted an interest in quicker, cheaper and more readily automated methods. In this paper a radioimmunoassay for human growth hormone in plasma is described which, by using activated charcoal for separation of free from bound labelled hormone, provides a significant saving in time, money, and equipment.

Under the conditions of radioimmunoassay both bound and free labelled hormone are soluble, and a variety of separation procedures have been developed. Activated charcoal was first used in a saturation analysis by Ekins and Sgherzi (1965) and by Gottlieb, Lau, Wasserman, and Herbert (1965) in the assay of vitamin $B_{12}$. Its use was subsequently described by Herbert in the radioimmunoassay of insulin (Herbert, Lau, Gottlieb, and Bleicher, 1965) and growth hormone (Lau, Gottlieb, and Herbert, 1966). However, in the assay of human growth hormone certain problems remain (Herbert, 1968).

The principle of the method is that free labelled peptide will bind to the charcoal particles and by suspending the charcoal in appropriate media the antibody-bound labelled peptide can be excluded. Removal of the supernatant after centrifugation of the charcoal allows the separation of free from bound labelled hormone in the whole incubation volume.

Present address: Harbor General Hospital, 1000 West Carson Street, Torrance, California 90509.

Received for publication 4 March 1969

\section{MATERIALS AND METHODS}

HUMAN GROWTH HORMONE ${ }^{1}$ This was used for iodination and standards.

\section{ANTIGROWTH HORMONE ANTISERA ${ }^{2}$ Two were used.}

DILUENT This was a solution of crystallized bovine albumin $(5 \mathrm{mg} / \mathrm{ml})$ in 0.07 molar barbitone buffer $p \mathrm{H} 8.6$, containing horse serum in a dilution of $1 / 80$. This was used for diluting standard human growth hormone, antisera and labelled hormone and for equalizing the incubation volumes.

HUMAN GROWTH HORMONE FREE PLASMA AND SERUM These were obtained from established cases of hypopituitarism.

CHARCOAL-DEXTRAN SUSPENSION One gram of Dextran ' $\mathrm{C}$ ' (BDH) was dissolved in $100 \mathrm{ml}$ of barbitone buffer. This was added to an equal volume of barbitone buffer containing $10 \mathrm{~g}$ of Norit 01 charcoal. The mixture was stored at $4^{\circ} \mathrm{C}$ and was mixed electromagnetically during use; $\mathbf{4 0 0 \mu l}$ (containing $20 \mathrm{mg}$ charcoal, $2 \mathrm{mg}$ Dextran) was added to the tubes with a spring-loaded syringe. The tubes were touched on a vortex mixer and then centrifuged in batches of 96 at $4^{\circ} \mathrm{C}$ for 20 minutes at $2,000 \mathrm{revs} / \mathrm{min}$. The supernatants were removed with a small-bore Pasteur pipette, and charcoal and supernatant tubes were counted in a Packard auto spectrometer with automatic background subtraction.

${ }^{1}$ Supplied by Dr A. E. Wilhelmi (N.I.H. GH-H.S. 722A) through the National Pituitary Agency of the United States.

2One serum was supplied by Dr S. A. Berson through the National Pituitary Agency of the United States, the other was received as a gift from Dr A. D. Wright of the Royal Postgraduate Medical School. 
${ }^{131}$ I-LABELLED HUMAN GROWTH HORMONE This was prepared by the method of Hunter and Greenwood (1962) with minor modifications. The reagents were added at room temperature to a conical reaction vial in the following order:

$1400 \mu \mathrm{l}$ of $0.5 \mathrm{M}$ phosphate buffer $p \mathrm{H} 7.5$

$210 \mu \mathrm{l}$ of a $200 \mathrm{mCi} / \mathrm{ml}$ solution of $\mathrm{Na}^{131} \mathrm{I} \ldots \ldots \ldots \ldots \ldots 2 \mathrm{mCi}$

$325 \mu \mathrm{l}$ of a $200 \mu \mathrm{g} / \mathrm{ml}$ solution of human growth hormone $5 \mu \mathrm{g}$

$425 \mu \mathrm{l}$ of a $2 \mathrm{mg} / \mathrm{ml}$ solution of chloramine-T . .........50 $\mu \mathrm{g}$

$5100 \mu \mathrm{l}$ of a $2.4 \mathrm{mg} / \mathrm{ml}$ solution of $\mathrm{Na}$ metabisulphate $\ldots .240 \mu \mathrm{g}$

$6100 \mu \mathrm{l}$ of a $10 \mathrm{mg} / \mathrm{ml}$ solution of potassium iodide $\ldots \ldots \ldots 1 \mathrm{mg}$

Reagents 3-6 were dissolved in 0.05 $\mathrm{M}$-phosphate buffer, $p \mathrm{H} 7 \cdot 5$

The last four additions were made, as rapidly as possible, with microcap pipettes, and the contents of the reaction vial were mixed by bubbling air through each microcap. After the last addition, the reaction mixture was added, as quickly as possible, to a $10 \mathrm{~cm}$ G-50 Sephadex column, which had been equilibrated at room temperature with barbitone buffer and saturated with $400 \mu \mathrm{l}$ of a $500 \mathrm{mg} / \mathrm{ml}$ solution of crystalline bovine albumin in barbitone buffer. The reaction vial was washed with a further $100 \mu \mathrm{l}$ of the potassium iodide solution and the washings were added to the column.The reaction vial was counted in an ionization chamber before the human growth hormone was added and after the mixture was transferred to the Sephadex column, and the residual radioactivity was always less than $1 \%$ of the total amount used.

Unreacted $\mathrm{Na}^{131}$ I was separated from labelled human growth hormone by elution from the column with barbitone buffer. Eluates, each of $0.5 \mathrm{ml}$, were collected into $0.5 \mathrm{ml}$ of a $50 \mathrm{mg} / \mathrm{ml}$ solution of crystalline bovine albumin in this buffer, and the eluates were counted and frozen immediately. It was found by incubating equivalent amounts of labelled human growth hormone from each eluate in series of tubes, as used for the standard curve, that the eluates from the trailing edge of the peptide peak produced the steepest curves. These fractions also produced the greatest binding to antibody and adsorption to charcoal. A simpler technique was then developed to select the best fraction by incubating arbitrary $1 / 100$ dilutions of the eluates in tubes containing diluent or antibody and human growth hormone-free plasma, for 30 minutes at $37^{\circ} \mathrm{C}$. That fraction which bound best to antibody, was adsorbed best to charcoal, and contained the greatest amount of radioactivity was selected for subsequent use. It was then diluted so that $50 \mu \mathrm{l}$ contained 2,000 to $4,000 \mathrm{cpm}$ on the day of iodination, and stored at $-4^{\circ} \mathrm{C}$ at the working dilution. Under the conditions described, fractions which produced less than $80 \%$ of counts adsorbed to charcoal in the absence of antibody, or less than $80 \%$ of counts bound in the presence of excess antibody, did not produce standard curves of sufficient slope to be useful in the radioimmunoassay. However, it should be noted that when the conditions of incubation were altered to those of the assay, there was a loss of adsorption of the labelled growth hormone to charcoal, but an increase in binding to antibody and in the slope of the standard curve.

Sixty iodinations (57 with $\mathrm{Na}^{131} \mathrm{I}$ and three with $\mathrm{Na}^{125} \mathrm{I}$ ) have been performed. In spite of using a constant amount of chloramine-T, the transfer of ${ }^{131} \mathbf{I}$ to human growth hormone and the damage to the labelled preparation has varied considerably. There is evidence (Berson and Yalow, 1966) that variations in the isotope are of importance. A distinct improvement was observed when $\mathrm{Na}^{131}$ I was obtained from the Radiochemical Centre (Amersham) in a dilution of $200 \mathrm{mCi} / \mathrm{ml}$ instead of the usual $40 \mathrm{mCi} / \mathrm{ml}$ solution. The range of specific activities was $80-300 \mu \mathrm{Ci} / \mu \mathrm{g}$ and it was found that lower specific activity iodinations were associated with less damage in the preparation. That the least damaged labelled human growth hormone was consistently found on the trailing edge of the peptide peak suggests that damage in preparation is associated with larger molecules than undamaged human growth hormone- ${ }^{131}$ I (Monjardino, Bryant, Stephenson, and Greenwood, 1968).

THE ASSAY The volumes of individual reagents are indicated in the protocol.

Sample tubes contained $350 \mu$ l of diluent added with a $1 \mathrm{ml}$ graduated pipette, $50 \mu \mathrm{l}$ of a solution of antiserum (in an initial dilution of $1 / 10^{5}$ ) added with a repeater Hamilton pipette, and $50 \mu$ of the plasma to be assayed added with a disposable microcap pipette. Control tubes contained $400 \mu \mathrm{l}$ of diluent and $50 \mu \mathrm{l}$ of plasma. Tubes for the standard curve contained $50 \mu \mathrm{l}$ each of antiserum and human growth hormone-free plasma and doubling volumes, starting with $10 \mu \mathrm{l}$ of a stock solution of human growth hormone of $10 \mathrm{ng} / \mathrm{ml}$, which was added with a Hamilton syringe. The volumes were equalized with diluent. 'Blank' tubes, containing human growth hormonefree plasma and diluent, and the human growth hormonefree tubes of the standard curve, were set up in quadruplicate. The remaining tubes of the standard curve and the plasma samples and their appropriate control tubes were set up in duplicate. The standards cover the range equivalent to 2 to $64 \mathrm{ng} / \mathrm{ml}$ of undiluted plasma. Plasma from acromegalic patients was assayed after dilution with human growth hormone-free plasma and $50 \mu \mathrm{l}$ of the diluted plasma was added to the assay. Alternatively, smaller amounts of plasma were added to the sample, control, and standard tubes, but the former method retained a greater flexibility in the assay and allowed the concurrent measurement of pre- and post-treatment samples. When serum samples were assayed human growth hormone-free serum was added to the standard tubes, but the assay was otherwise unaffected.

Labelled human growth hormone $(50 \mu \mathrm{l})$ was added with a repeater Hamilton pipette after a preliminary period of incubation of 24 to 36 hours. The total period of incubation was five to seven days and both stages proceeded at $4^{\circ} \mathrm{C}$.

At the end of incubation $400 \mu \mathrm{l}$ of the charcoaldextran suspension was used for separating bound from free labelled human growth hormone.

CALCULATIONS A correction factor for the estimate of antibody-bound counts was necessary because of the failure of the preparations of labelled human growth hormone to adsorb completely to charcoal when no specific antigrowth hormone antiserum was present. The counts remaining in the supernatant under these 
conditions were shown by chromato-electrophoresis to represent at least three components: damaged ${ }^{131} \mathrm{I}$ human growth hormone; ${ }^{131}$ I eluted from the labelled hormone during incubation; and 'free', presumably immunologically intact, ${ }^{131}$ I-human growth hormone. The method of correction used was that the counts in the supernatant in the tubes without antibody were subtracted from the counts in the supernatant in the corresponding tubes with antibody to give an estimate of the antibody bound counts. The figure for the corrected bound counts was divided by the counts in the charcoal to give the bound-to-free ratio, and added to the counts in the charcoal to give bound plus free counts, from which the percentage bound was calculated. In the standard curve, the mean of the quadruplicate blank tubes was used to correct the bound counts, the counts remaining in the supernatant in the absence of antibody having been shown to be unaffected by the small amounts of unlabelled human growth hormone added to the standard tubes.

\section{STUDIES ON THE SEPARATION PROCEDURE}

A number of problems in the use of charcoal dextran suspensions for the separation of bound from free labelled human growth hormone have been found (Herbert, 1968). In the following sections, the experiments performed to establish the optimum conditions for the separation procedure are described.

THE QUANTITY OF CHARCOAL USED A constant amount of labelled human growth hormone was incubated in the presence of $50 \mu \mathrm{l}$ of human growth hormone-free plasma with either diluent, or a constant amount of specific antigrowth hormone antiserum, sufficient to bind over $50 \%$ of the labelled hormone. The final volume of incubate was $500 \mu \mathrm{l}$. After a five-day incubation a suspension of charcoaldextran was added to the tubes which were then centrifuged and the supernatants removed. It will be seen (Fig. 1) that the proportion of counts remaining in the supernatant in the absence of antibody (= percentage blank) fell progressively as the quantity of charcoal used was increased. There was also a fall in the proportion of counts in the supernatant in the tubes with antibody as the quantity of charcoal rose. However, only when $40 \mathrm{mg}$ of charcoal was used was there any significant drop in the 'calculated' percentage of antibody-bound counts. When small amounts of charcoal were used, $e g, 5 \mathrm{mg} /$ tube, the percentage blank was so high that it was difficult to observe small changes in the ratio of bound to free human growth hormone. In all subsequent experiments $20 \mathrm{mg}$ charcoal per tube was used. No significant differences were noted between Norit 01, Norit A, and British Drug Houses activated charcoal.

In a similar experiment the length of time the charcoal was in contact with the incubate before

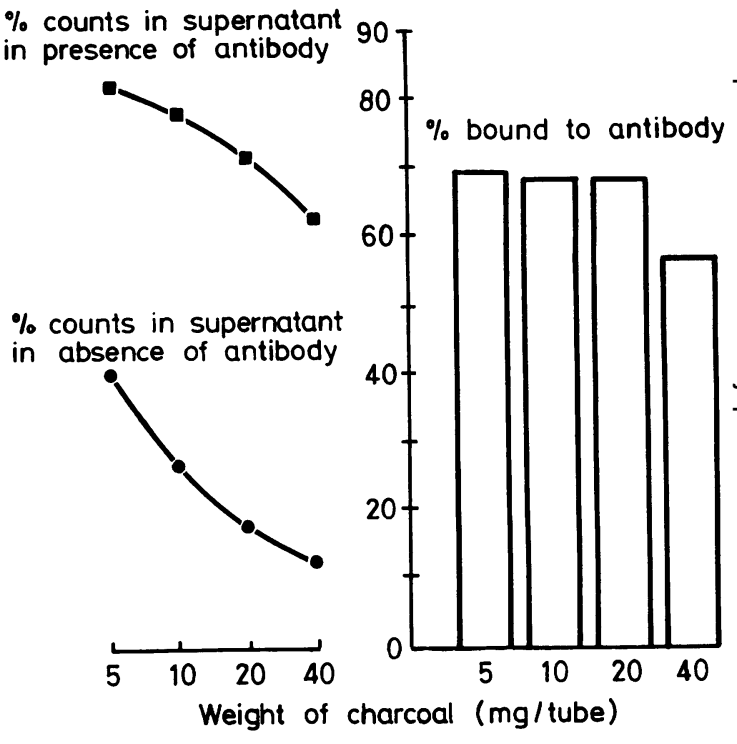

FIG. 1. The effect of increasing the amount of charcoal from 5 to $40 \mathrm{mg}$ per tube on the separation of bound from $\vec{\varphi}$ free labelled human growth hormone. The calculation 9 of the percentage bound is indicated on the text.

centrifugation was varied. No significant difference was noted in the percentage bound if the charcoal $\frac{\circ}{\circ}$ was separated as quickly as possible or left for $30 \cong$ or 120 minutes. Leaving the charcoal in contacto with the incubate for 24 hours resulted in a technically difficult separation and also led to a significant reduction in bound counts, presumably because the removal of free human growth hormone by the charcoal led to the dissociation of the human growth hormone antibody complex.

THE USE OF DEXTRAN Published methods for the immunoassay of human growth hormone and insulin using charcoal include the use of dextran 'coating' of the charcoal,'but that this is not an absolute require-o ment of the separation procedure has been demon- $\bar{N}$ strated by Ekins and Sgherzi (1965) in the assay of ${ }^{\circ}$ vitamin $B_{12}$ and insulin (Ekins, 1968). In an experi- $N$ ment where $20 \mathrm{mg}$ charcoal per tube was suspended $N$ in various dextrans and used for separation of free from bound labelled human growth hormone, the effect of the dextrans was compared with the effect $\frac{D}{\Phi}$ of suspending the charcoal in barbitone buffer alone $\stackrel{\oplus}{+}$ and in diluent. The incubation tubes were prepared 0 and incubated as in the above experiments. It willo be seen from Table I that an adequate separation $\stackrel{\Phi}{\overparen{D}}$ can be achieved without the use of dextran but the $\mathbb{Q}$ use of Dextran C British Drug Houses (BDH) and 110 Pharmacia resulted in the greatest calculated 
TABLE I

EFFECT OF SUSPENDING THE CHARCOAL IN VARIOUS MEDIA

\begin{tabular}{|c|c|c|c|c|}
\hline \multicolumn{2}{|l|}{ Medium } & \multirow[t]{2}{*}{ Molar Weight } & Percentage Blank & Percentage 'Bound' \\
\hline Buffer & & & $16 \cdot 6$ & $62 \cdot 3$ \\
\hline Diluent & & & $25 \cdot 8$ & $72 \cdot 1$ \\
\hline Dextran ${ }^{1}$ & $\int 10$ & $(10,000)$ & $13 \cdot 8$ & $64 \cdot 3$ \\
\hline & 20 & $(20,000)$ & $14 \cdot 6$ & 58.9 \\
\hline & 80 & $(80,000)$ & $15 \cdot 6$ & $67 \cdot 1$ \\
\hline Pharmacia & 110 & $(110,000)$ & $16 \cdot 6$ & $70 \cdot 3$ \\
\hline & 250 & $(250,000)$ & $28 \cdot 1$ & $65 \cdot 3$ \\
\hline & 500 & $(500,000)$ & $26 \cdot 7$ & $71 \cdot 0$ \\
\hline & 2000 & $\left(2 \times 10^{6}\right)$ & $26 \cdot 3$ & $66 \cdot 2$ \\
\hline & & $(200,000-275,000)$ & $18 \cdot 6$ & 66.9 \\
\hline BDH & B & $(150,000-200,000)$ & $17 \cdot 9$ & 65.9 \\
\hline & $\mathrm{C}$ & $60,000-90,000)$ & 16.9 & $71 \cdot 4$ \\
\hline
\end{tabular}

percentage bound with the smallest percentage blank. Dextran $\mathrm{C}$ was used in all subsequent experiments. A similar experiment was performed in which the quantity of dextran was varied in relation to the amount of charcoal used and no difference was noted when 2,5 , or $10 \mathrm{mg}$ of dextran per $20 \mathrm{mg}$ of charcoal was added to the tubes. There was a definite loss of effect with less than $2 \mathrm{mg}$ and this amount was used in all subsequent experiments.

THE EFFECT OF PROTEIN Herbert (1968) found that erratic results were obtained using dextran-coated charcoal in the immunoassay of growth hormone until $0.1 \mathrm{ml}$ of plasma was added empirically to every sample, including the standard tubes. Experiments have been undertaken to study the effect of plasma on the immunoassay system. It was shown that different plasmas effected the separation procedure differently, and the effect of differing quantities of the same plasma was examined. Experiments indicating an effect independent of the separation procedure were also performed.

In two experiments, labelled human growth hormone was incubated for six days at $4^{\circ} \mathrm{C}$ with diluent and $50 \mu \mathrm{l}$ aliquots of growth-hormone-free plasma in a final volume of $500 \mu l$. Dextran-coated charcoal was then added; the coefficient of variation of the percentage of counts remaining in the supernatant of each tube was $1.7 \%$ for 16 samples in the first experiment and $1.4 \%$ for 18 samples in the second experiment. However, when groups of seven samples from each of five patients were examined in the same way in a single assay, for each group the coefficient of variation of the percentage counts in the supernatant in the tubes without antibody varied from 1.5 to $15.0 \%$. It was thus clear that the precise proportion of the counts in the supernatant in the tubes without antibody could not be assumed, and in all assays control tubes, without antibody, were set up for each sample and treated identically to the assay tubes.

The effect of increasing the quantity of the same plasma present in the incubate was then studied. Labelled human growth hormone and antibody were incubated at $4^{\circ} \mathrm{C}$ for five days in increasing concentra-

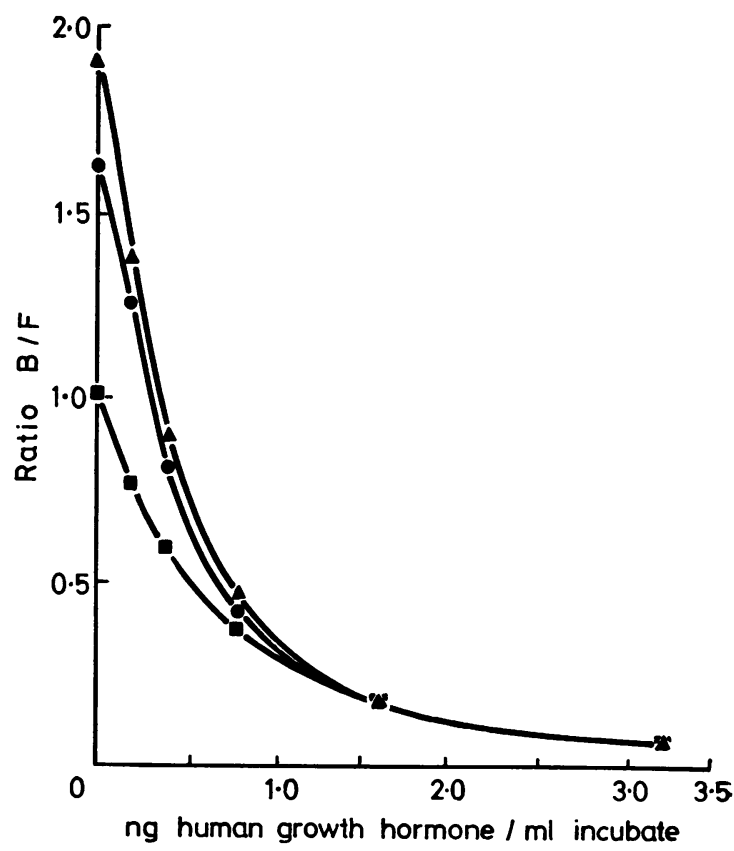

FIG. 2. The effect of increasing the amount of human growth hormone (HGH)-free plasma in the incubate on the standard curve.

$\Delta-\Delta 50 \mu l$ of $\mathrm{HGH}$-free plasma, final concentration $1 / 10$ $100 \mu \mathrm{l}$ of $\mathrm{HGH}$-free plasma, final concentration $1 / 5$ $200 \mu l$ of $H G H$-free plasma, final concentration $1 / 2 \cdot 5$ 
TABLE II

PROTOCOL FOR STANDARD AND ASSAY TUBES ${ }^{1}$

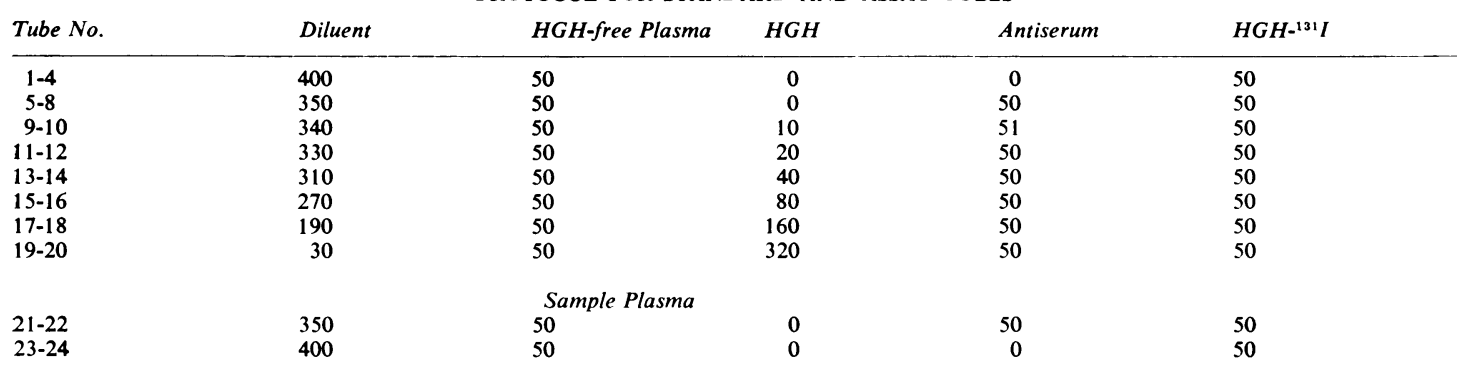

${ }^{1}$ All volumes in microlitres.

tions $(1 / 10,1 / 5,1 / 2 \cdot 5)$ corresponding to $50 \mu 1$, $100 \mu \mathrm{l}, 200 \mu \mathrm{l})$ of human growth hormone-free plasma in a final volume to $500 \mu \mathrm{l}$. Figure 2 shows the effect on the standard curve: the three series of standard tubes had identical label, antibody, and standard human growth hormone concentrations and differed only in that the protein concentration increased from $1 / 10$ to $1 / 2 \cdot 5$. It will be seen that adequate calibration curves could be obtained at any of these dilutions but that it was necessary for the protein concentration to be identical throughout all assay tubes. When samples with high endogenous human growth hormone levels were assayed they were diluted in human growth hormone-free plasma.

Further studies have suggested that the effects of plasma are not only upon the separation procedure. In the course of four assays, a second series of standard tubes was included in which the incubation proceeded in the absence of plasma, but aliquots of human growth hormone-free plasma, which had been used in the reference standard tubes, were added in identical amounts immediately before the separation procedure. Figure 3 shows the typical results of one such experiment, and it will be seen that the standard curves do not form an asymptote, indicating a difference in the binding constant of the antigen-antibody reaction in the presence and absence of plasma. It seems, therefore, that plasma affects the radioimmunoassay system both at the level of the primary antigen antibody reaction as well as affecting the charcoal separation procedure.

THE CONDITIONS OF INCUBATION The slope of the standard curve is dependent upon a number of factors of which the most important are the binding characteristics of the antibody and the time and temperature of the incubation. In common with other workers it was found that a 'disequilibrium incubation' (Samols and Bilkus, 1964) increased the slope of the standard curve, and routinely the addition of the label was delayed by one to two days. The을 rapidity with which batches of tubes may be separated with charcoal makes short periods, $Z$ although ultimately the use of a very short incubation? period must be dependent upon the avidity of the 3 antiserum rather than the technique of separation. Figure 4 shows the increase in binding of $0.02 \mathrm{ng}$ of labelled human growth hormone to $500 \mu \mathrm{l}$ of Wright

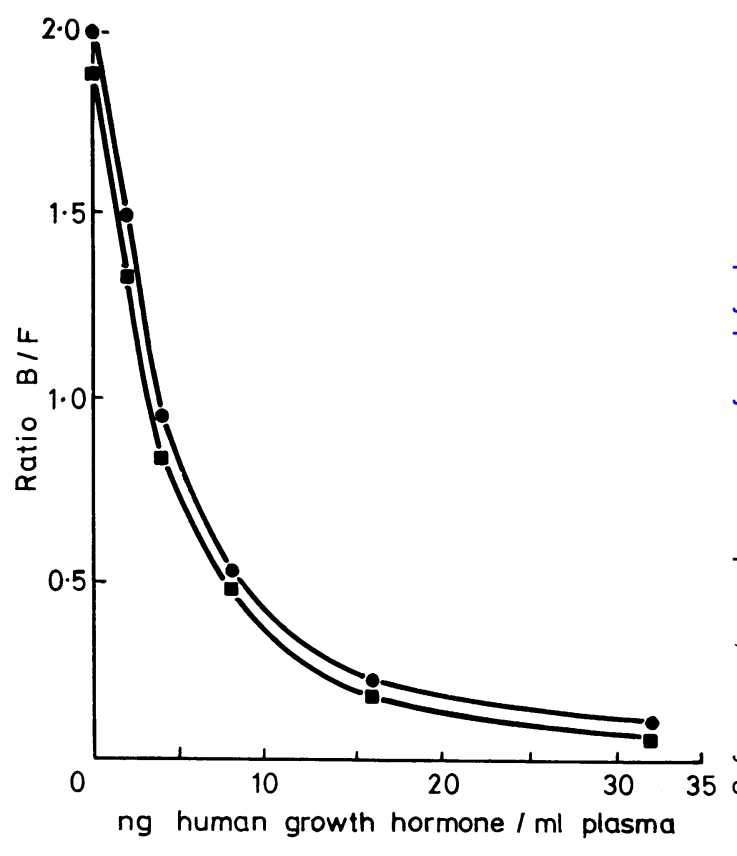

FIG. 3. The effect on the standard curve of adding the human growth hormone-free plasma at the beginning of the $\overline{\mathrm{O}}$ incubation and immediately before charcoal was added迎 at the end of the incubation.

HGH-free plasma added at the end of incubation $\cong$ $H G H$-free plasma included in the incubation 


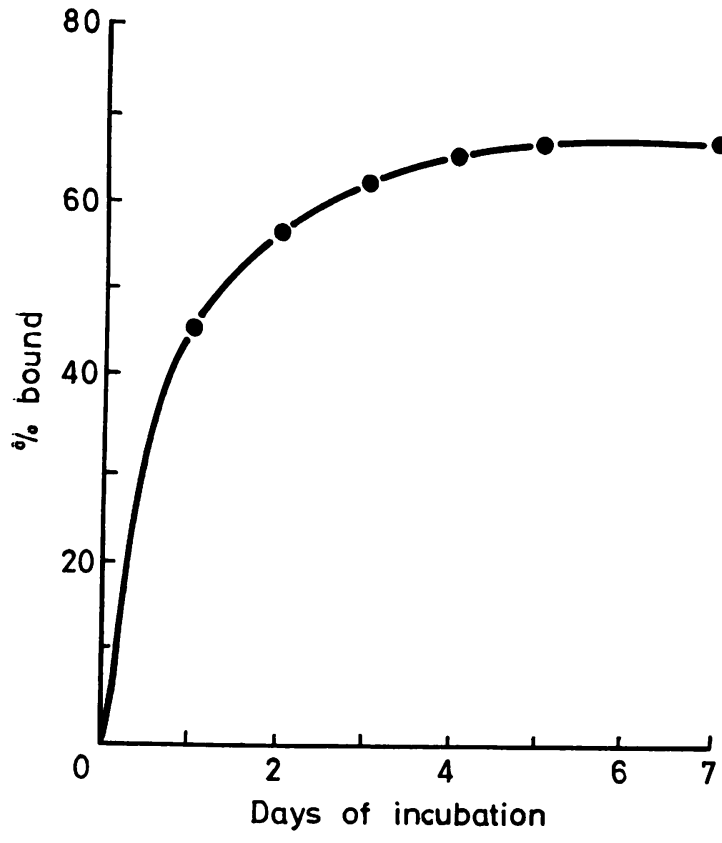

FIG. 4. The binding after various periods of incubation of $0.02 \mathrm{ng}$ of ${ }^{131} \mathrm{I}-\mathrm{HGH}$ to $500 \mu \mathrm{l}$ of Wright antiserum at a final concentration of $1 / 10^{6}$.

antibody at a final dilution of $1 / 10^{6}$ after periods of incubation of one to seven days at $4^{\circ} \mathrm{C}$. In routine assays laboratory convenience lead to a total incubation period at $4^{\circ} \mathrm{C}$ of between five and eight days with a preincubation period without label of 24 to 48 hours.

Incubation at $37^{\circ} \mathrm{C}$ overnight gave a standard curve with a slope similar to a 48-hour incubation at $4^{\circ} \mathrm{C}$, and was convenient for evaluating iodinations and for screening plasmas from patients with acromegaly, to determine the best dilution for use in a subsequent more precise assay.

\section{VALIDATION OF THE ASSAY TECHNIQUE}

The validity of the assay has been assessed in the following ways:

REPRODUCIBILITY Two samples were assayed six times within a single assay with the following results:

\begin{tabular}{lrr} 
& \multicolumn{1}{c}{ Mean } & $S D$ \\
\hline Sample 1 & $6.2 \mathrm{ng} / \mathrm{ml} \pm$ & 0.24 \\
Sample 2 & $14.0 \mathrm{ng} / \mathrm{ml} \pm$ & 1.51
\end{tabular}

Three samples were assayed in four separate assays, using different preparations of human growth hormone-131I, with the following results:

\begin{tabular}{lrl} 
& \multicolumn{1}{c}{ Mean } & $S D$ \\
\hline Sample 3 & $5 \cdot 7 \pm$ & 0.54 \\
Sample 4 & $10 \cdot 1 \pm$ & 1.44 \\
Sample 5 & $20 \cdot 1 \pm$ & 2.58
\end{tabular}

RECOVERY Growth hormone was added to 34 plasma samples by a colleague and the samples were then assayed blind in four assays. The results are shown in the accompanying table:

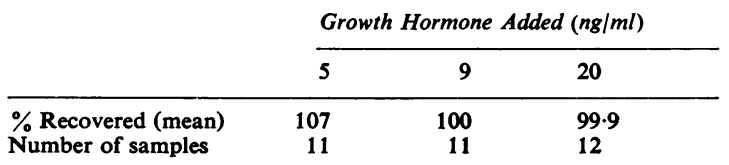

The mean recovery for all the samples was $102 \cdot 5 \% \pm$ $19 \cdot 2(\mathrm{SD}) \mathrm{n}=34$.

SPECIFICITY The specificity of the assay has been assessed by assaying a number of samples from normal patients, patients with acromegaly, and one patient with cerebral gigantism in two assays, one with Wright antiserum and one with Berson antiserum. The relationship of standard to plasma growth hormone was reflected by a correlation coefficient of 0.99 for 14 samples assayed with these two antisera. This contrasted with the results obtained when 20 plasmas from women in the last trimester of pregnancy were assayed in this way. In the latter experiment the correlation coefficient was $0 \cdot 88$, the difference between these two correlation coefficients being highly significant $(1 / 2, P=$ 0.0008 ). This difference was attributed to the presence of placental lactogen (Greenwood, Hunter, and Klopper, 1964). The results are summarized in Figure 5.

SENSITIVITY The sensitivity of the assay depends upon the precision of the measurement of the percentage bound or $\mathrm{B} / \mathrm{F}$ ratio and the slope of the standard curve. With a given slope the sensitivity is dependent upon the ability to measure a statistically significant difference between two values, one of which is zero. To aid evaluation, the tube in the standard curve with no added human growth hormone has been run in quadruplicate, and the sensitivity has been calculated by applying twice the standard deviation of the percentage bound obtained at this point to the standard curve. The mean sensitivity of 21 consecutive assays of plasma samples at a 1/10 final concentration was 0.41 $\mathrm{ng} / \mathrm{ml}$ plasma (range 0.18 to 0.90 ).

In order to assess further the sensitivity and specificity obtainable using charcoal for separation of 


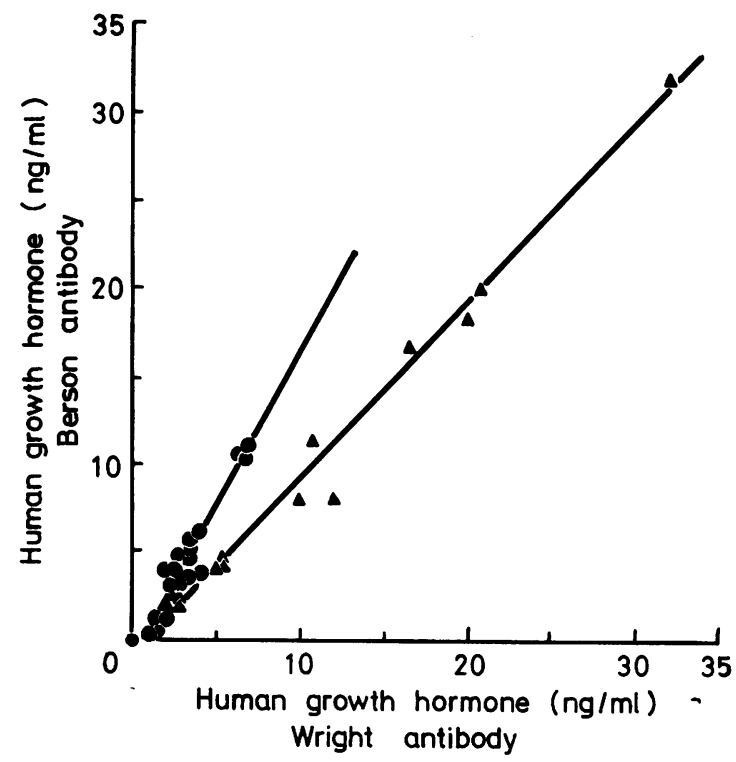

FIG. 5 .

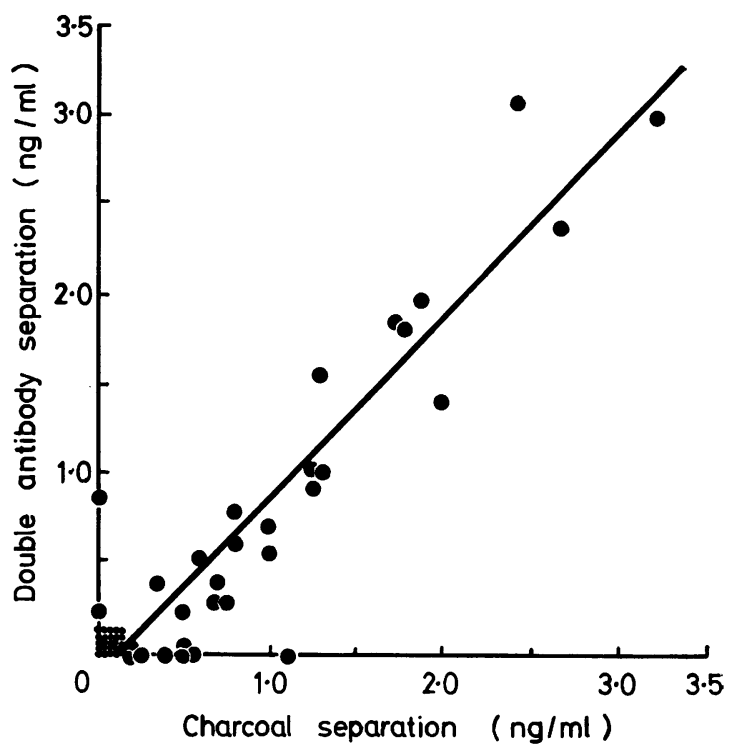

FIG. 6.

FIG. 5. Results and regression line for samples measured with two antisera, for normal subjects, patients with acromegaly, and one patient with cerebral gigantism $(\mathbf{\Delta})$ compared with results and regression line for samples from women in the last trimester of pregnancy $(O)$.

Normal subjects: $y=1.01 x-0.95, r=0.99, p<0.001, n=14$

Pregnancy samples: $y=1 \cdot 62 x-1 \cdot 29, r=0 \cdot 88, p<0 \cdot 001, n=20$

The difference between the two correlation coefficients (by $Z$ conversion, $t=3.1551 \frac{1}{2} p=0.0008$ ) was highly significant.

FIG. 6. Results in 63 samples assayed with charcoal separation method and by Dr P. H. Sonksen with double antibody separation technique: $y=1.01 x-0.10, r=0.93, p<0.001, n=63$.

free from bound labelled human growth hormone, 63 samples from five healthy normal males under basal conditions were assayed by the author using the charcoal method and by Dr P. H. Sonksen using a double antibody method (Boden and Soeldner, 1967). Figure 6 shows the results obtained. In this study, while the standards used were both Wilhelmi's highly purified human growth hormone, the antisera differed. The correlation coefficient was 0.93 .

\section{DISCUSSION}

The use of charcoal is but one of a number of adsorption procedures developed for the separation of bound from free labelled hormones. The first adsorption technique described for this purpose was chromato-electrophoresis but this suffers from several disadvantages, not least of which is the limited and variable capacity of the paper to bind the labelled hormone in the presence of plasma. This disadvantage can be overcome by procedures in which the adsorbent is added to the incubate, for the amount of the former can be varied and the whole of the latter is examined, rather than an aliquot as in chromato-electrophoresis. The amount of charcoal used in any radioimmunoassay will depend upon the adsorption properties of the labelled hormone and the quantity of plasma or serum in the incubate. The relationship of the amount of charcoal used in this assay for human growth hormone to that used in published assays for insulin (Herbert et al, 1965) and ACTH (Donald, 1968) is sinilar to the amounts of talc and silica proposed by Rosselin, Assan, Yalow, and Berson (1966) for these hormones.

A further advantage in examining the whole of the incubate lies in the ability to use labelled preparations of a lower specific activity than that required for chromato-electrophoresis. With human growth hormone damage during preparation in high specific activity iodinations is considerable; it is greatly reduced when less radioactivity is transferred. The rapidity of the charcoal separation makes it a useful method for screening preparations of labelled human 
growth hormone and testing them within the context of the system in which they are to be used. Implicit in the methods described for selecting the eluates is the recognition that the adsorption properties of ${ }^{131}$ I-human growth hormone, while paralleling immunological integrity, are not identical to it.

Dextran appears to play no fundamental role in the separation of bound from free labelled human growth hormone. The radioimmunoassay of insulin can be performed satisfactorily without it (Ekins, 1968) though it has been shown to help in the formation of a compact charcoal 'button' by Donald (1968). In the assay of human growth hormone dextran provides small but definite advantages.

It is important to emphasize the effect of protein. In any assay system, a priori the samples should differ from the standards only in that the value to be measured is unknown. It was initially thought that plasma only affected the separation procedure, but the experiment illustrated in Fig. 3 demonstrates the effect on the equilibrium of the antibody-antigen reaction and stresses the importance of an identity of protein concentration throughout the assay. That this fundamental principle is not restricted to the use of activated charcoal in the assay of human growth hormone is illustrated by the results reported by Odell (1968) using a second antibody technique for the measurement of serum gonadotrophins.

The sensitivity obtained with this method compares favourably with that obtained using other methods of separation and the simplicity and speed result in a high degree of reproducibility.

The excellent technical assistance of Mrs Suzanne Guy is acknowledged. It is a pleasure to record my thanks to Dr J. D. N. Nabarro for help and encouragement.

\section{REFERENCES}

Berson, S. A., and Yalow, R. S. (1966). Science, 152, 205.

Boden, G., and Soeldner, J. S. (1967). Diabetologia, 3, 413.

Donald, R. A. (1968). J. Endocrinol., 41, 499-508.

Ekins, R. P. (1968). In Protein and Polypeptide Hormones (Proceedings of the International Symposium, Liege, 1968). Vol. 4, Excerpta Medica Amsterdam.

-, and Sgherzi, A. M. (1965). Radiochemical Methods of Analysis, vol. 2, 239. International Atomic Energy Agency, Vienna.

Gottlieb, C. W., Lau, K.S., Wasserman, L. R., and Herbert, V. (1965). Blood, 25, 875 .

Greenwood, F. C., Hunter, W. M., and Klopper, A. (1964). Brit. med. J., $1,22$.

Herbert, V. (1968) In Protein and Polypeptide Hormones (Proceedings of the International Symposium, Liege, 1968) vol. 1, p. 55. Excerpta Medica, Amsterdam.

—, Lau, K. S., Gottlieb, C. W., and Bleicher, S. J. (1965). J. clin. Endocr. Metab., 25, 1375.

Hunter, W. M., and Greenwood, F. C. (1962). Nature (Lond.), 194, 495. -, (1964). Biochem. J., 91, 43.

Lau, K. S., Gottlieb, C. W., and Herbert, V. (1966). Proc. Soc.exp. Biol. (N.Y.), 123, 126.

Monjardino, J. P., Bryant, G. D., Stephenson, F. L., and Greenwood, F. C. (1968). In Protein and Polypeptide Hormones (Proceedings of the International Symposium, Liege, 1968 vol. 1, p. 34.) Excerpta Medica, Amsterdam.

Odell, W. D., Parlow, A. F., Cargille, C. M., and Ross, G. T. (1968). J. clin. Invest., 47, 2551.

Rosselin, G., Assan, R., Yalow, R. S., and Berson, S. A. (1966). Nature (Lond.), 212, 355.

Samols, E., and Bilkus, D. (1964). Proc. Soc. exp. Biol. (N.Y.), $115,79$.

\section{ADDENDUM}

Since the submission of this paper, an article describing the use of charcoal for the screening of iodination eluates of labelled human luteinizing hormone has been published (Abraham,, G. E. 1969, Clin. Chem., 14, 230). 